\title{
State Energy Severance Taxes, 1985-1993
}

\author{
September 1995
}

\author{
Energy Information Administration \\ Office of Energy Markets and End Use \\ U.S. Department of Energy \\ Washington, DC 20585
}

This report was prepared by the Energy Information Administration, the independent statistical and analytical agency within the Department of Energy. The information contained herein should not be construed as advocating or reflecting any policy position of the Department of Energy or of any other organization. 


\section{Contacts}

This report analyzes changes in aggregate and State-level energy severance taxes for 1985 through 1993 . Data are presented for crude oil, natural gas, and coal. The report highlights trends in severance tax receipts relative to energy prices and production, using severance tax data published by the Bureau of the Census of the U.S. Department of Commerce and production data published by the Energy Information Administration.

This report was prepared in the Office of Energy Markets and End Use of the Energy Information Administration, U.S. Department of Energy, under the general direction of W. Calvin Kilgore. The project was directed by Mark E. Rodekohr, Director of the Energy Markets and Contingency Information Division (202) 586-1130, and Mary E. Northup, Chief of the Financial Analysis Branch (202) 586-1445. For further information concerning this report, contact Marie N. Fagan (202) 586-1452, or Dennis W. Sumner (202) 586-8597.

This report is also available on the Internet (World Wide Web address: http://www.eia.doe.gov). 


\section{DISCLAIMER}

Portions of this document may be illegible in electronic image products. Images are produced from the best available original document. 


\section{Contents}

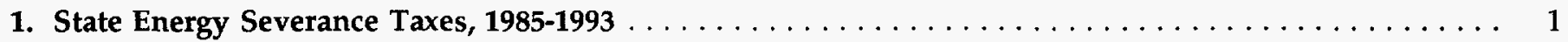

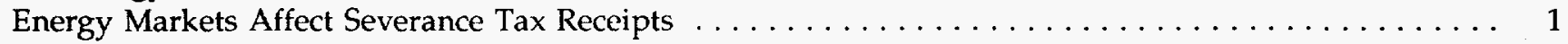

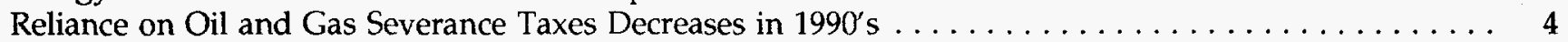

Coal Severance Tax Receipts Decline in the 1980 's, Recover in the 1990 's . . . . . . . . . . . . . 5

Appendix: Methodology and Data Sources

Energy Production under State Jurisdiction $\ldots \ldots \ldots \ldots \ldots \ldots \ldots \ldots \ldots \ldots \ldots \ldots \ldots \ldots \ldots$

Evaluating and Adjusting State Tax Receipt Data $\ldots \ldots \ldots \ldots \ldots \ldots \ldots \ldots \ldots \ldots \ldots \ldots \ldots$

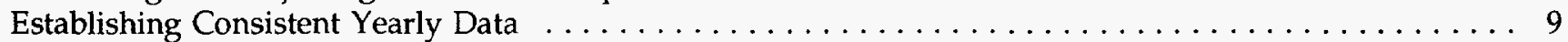

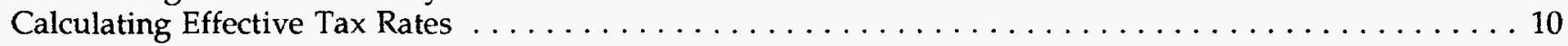

\section{Tables}

1. State Government Tax Receipts, Fiscal Years $1985-1993 \ldots \ldots \ldots \ldots \ldots \ldots \ldots \ldots \ldots \ldots \ldots \ldots \ldots$. . . . . . . 2

2. State Government Severance Tax Receipts For Top 8 Energy-Producing States,

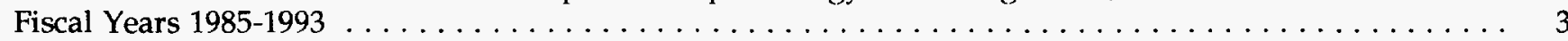

3. State Government Severance Taxes for Oil and Natural Gas,

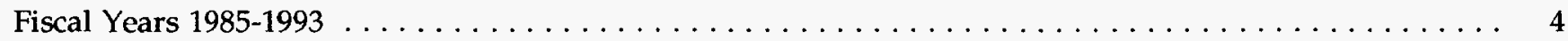

4. State Government Severance Taxes for Coal, Fiscal Years $1985-1993 \ldots \ldots \ldots \ldots \ldots \ldots \ldots \ldots \ldots$

A1. State Government Crude Oil and Natural Gas Severance Tax Receipts, Fiscal Years 1985-1993 . . . . . . 13

A2. State Government Coal Severance Tax Receipts, Fiscal Years $1985-1993 \ldots \ldots \ldots \ldots \ldots \ldots \ldots \ldots \ldots$

A3. Production of Oil Under State Jurisdiction, including Lease Condensate, Fiscal Years 1985-1993 . . . . . 15

A4. Marketed Production of Natural Gas (Wet) Under State Jurisdiction, Fiscal Years 1985-1993 . . . . . . . 16

A5. Production of Oil and Gas Under State Jurisdiction, Fiscal Years 1985-1993 . . . . . . . . . . . . . . . 17

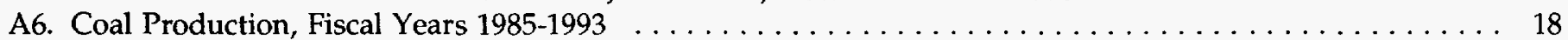

A7. State Government Crude Oil and Natural Gas Severance Tax Receipts, Fiscal Years 1972-1984 . . . . . . . 19

A8. State Government Coal Severance Tax Receipts, Fiscal Years $1972-1984 \ldots \ldots \ldots \ldots \ldots \ldots$

\section{Figures}

1. State Government Energy Severance Tax Receipts $\ldots \ldots \ldots \ldots \ldots \ldots \ldots \ldots \ldots \ldots \ldots \ldots \ldots \ldots \ldots$

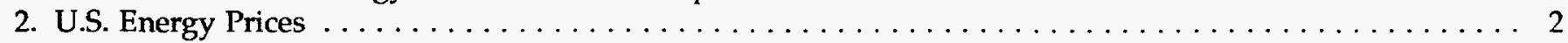

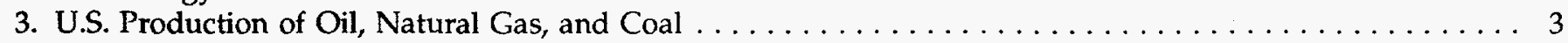

4. Energy Severance Tax Share of Taxes, Top 8 Energy-Producing States $\ldots \ldots \ldots \ldots \ldots \ldots \ldots \ldots$

5. Reliance on Oil and Gas Severance Taxes, Selected States $\ldots \ldots \ldots \ldots \ldots \ldots \ldots \ldots \ldots \ldots \ldots \ldots$

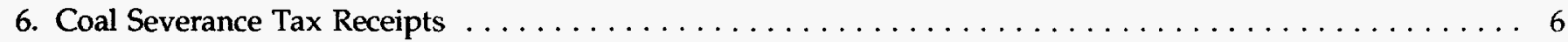

7. Effective Coal Severance Tax Rates, Top Three Coal-Producing States $\ldots \ldots \ldots \ldots \ldots \ldots \ldots \ldots \ldots$

8. Reliance on Coal Severance Taxes, Selected States $\ldots \ldots \ldots \ldots \ldots \ldots \ldots \ldots \ldots \ldots \ldots \ldots \ldots \ldots$ 


\section{State Energy Severance Taxes, 1985-1993}

In the United States, State governments often tax a portion of the value of natural resources extracted, or "severed." The States generally levy energy severance taxes in the form of a percent of the value of the resources removed or sold (an ad valorem tax), but sometimes tax the volume of the resource removed (a dollar-per-unit tax). In addition to severance taxes, royalty payments, income taxes, and property taxes related to energy production also contribute to State receipts from energy production.

State governments frequently regard severance taxes as a revenue source with a minimal burden to the State's own residents, especially if the taxed resources are produced by out-of-State companies or are exported to customers in other States. ${ }^{1}$ For example, North Dakota collects about 5 percent of its tax revenue through coal severance taxes. The coal is used for electricity generation within the State, with most of the electricity sold out of the State. Thus, a portion of the severance tax burden is transferred out of North Dakota. ${ }^{2}$

Although severance taxes can be an attractive source of revenue, they can inhibit development of a State's energy resources by increasing the cost of energy production. If the added cost of a State's severance tax cannot be passed along, the profitability of energy production deteriorates, making energy investment less attractive. An energyproducing State must balance the revenue effects and incentive effects of its severance taxes.

Despite the importance of severance taxes as a source of State funds and the effect of energy severance taxes on the cost of energy, published time series of effective tax rates (taxes relative to production) after 1987, have not been available. This report presents such a series on a consistent basis and provides a continuation of the series of State energy severance taxes presented in the earlier Energy Information Administration report, Energy Severance Taxes, 1972-1987. ${ }^{3}$ Consistent presentation of effective tax rates requires adjusting production data (available on a calendar year or monthly basis) for consistency with revenue data (available on a fiscal year basis). A description of these adjustments and computations, along with detailed State severance tax receipt data and energy production data are presented in the Appendix.

The next section of this report summarizes trends in energy severance taxes from 1985 (just before the 1986 oil price collapse) through $1993 .{ }^{4}$ Trends specific to severance taxes on oil, natural gas, and coal are separately reviewed in the rest of the report. The summary of trends by energy source, with the State-level tax receipt and production data available in the Appendix, will be of use to energy industry analysts and State fiscal and budget analysts, whose investigations and forecasts may depend on assumptions about severance tax rates.

\section{Energy Markets Affect Severance Tax Receipts}

Severance tax receipts generally depend on the price of energy, levels of hydrocarbon production, and the rate at which the States levy taxes. The oil price collapse of 1986 sharply reduced receipts from severance taxes (Figure 1 ). After 1987, low energy prices and the general lack of growth in energy production resulted in a flattening of

\footnotetext{
${ }^{1}$ Robert Deacon et.al., Taxing Energy: Oil Severance Taxation and the Economy, Independent Studies in Political Economy (New York: Holmes and Meier, 1990), p. 49.

'U.S. Bureau of the Census, Series GF/92-1, State Government Tax Collections: 1992, U.S. Government Printing Office, Washington, DC, 1994, and earlier issues, and U.S. Bureau of the Census, unpublished data. Energy Information Administration, State Coal Profiles, DOE/EIA-0567 (Washington, DC, January 1994), p. 67; and Energy Information Administration, State Energy Data Report 1993, DOE/EIA0214(93) (Washington, DC, May 1994), p. 233.

${ }^{3}$ Energy Information Administration, Energy Severance Taxes, 1972-1987, DOE/EIA-0519 (Washington, DC, August 1988).

${ }^{4}$ Historical severance tax data (from 1972-1984) can be found in Appendix Tables A7 and A8 of this report.
} 
severance tax collections (Figures 1, 2 and 3). In 1985, for example, the States as a group collected $\$ 7.0$ billion in energy severance taxes, 3.3 percent of all State tax receipts (Table 1). By 1993, energy severance tax collections fell to $\$ 4.6$ billion, 1.3 percent of State tax receipts.

Figure 1. State Government Energy Severance Tax Receipts

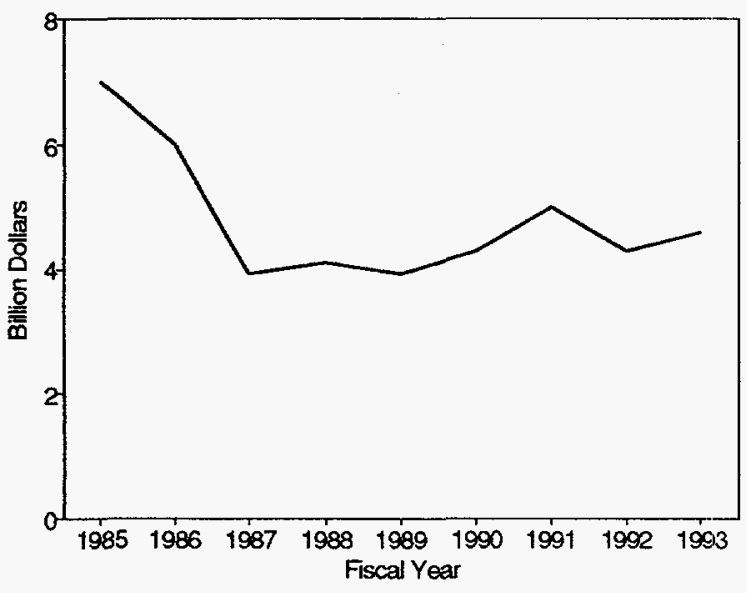

Source: U.S. Bureau of the Census, Series GF/92-1, State Government Tax Collections: 1992, U.S. Government Printing Office, Washington, DC, 1994, and earlier issues, and U.S. Bureau of the Census, unpublished data.
Figure 2. U.S. Energy Prices

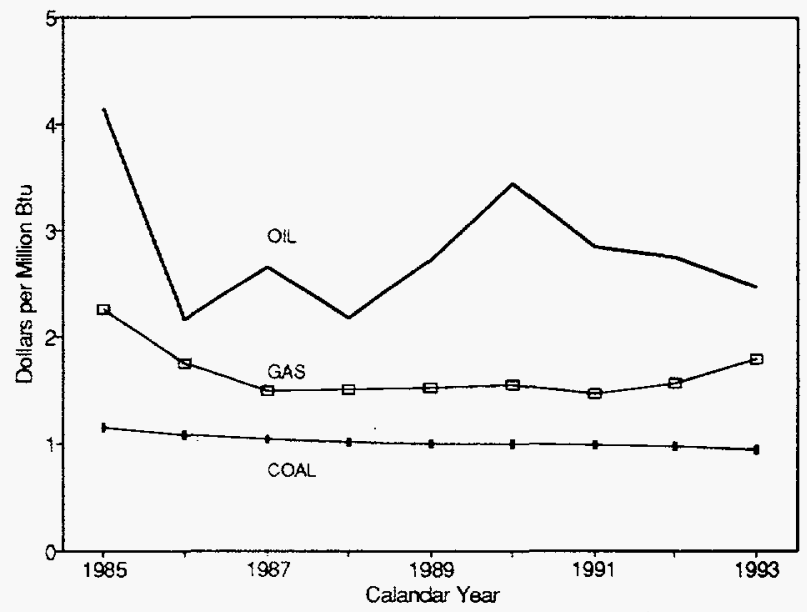

Note: Crude Oil Price is domestic first purchase price. Gas Price is the domestic wellhead price. Coal Price is mine price.

Source: Energy Information Administration, Annual Energy Review 1993. DOE/EIA-0384(93) (Washington, DC, July 1994), Table 3.1

Table 1. State Government Tax Receipts, Fiscal Years 1985-1993

\begin{tabular}{|c|c|c|c|}
\hline Fiscal Year & $\begin{array}{c}\text { Energy Severance Taxes } \\
\text { (billion dollars) }\end{array}$ & $\begin{array}{l}\text { Total State Taxes } \\
\text { (billion dollars) }\end{array}$ & $\begin{array}{l}\text { Percent of Tota } \\
\text { State Taxes }\end{array}$ \\
\hline $1985 \ldots \ldots \ldots \ldots \ldots$ & 7.0 & 215.9 & 3.3 \\
\hline $1986 \ldots \ldots \ldots \ldots \ldots$ & 6.0 & 228.3 & 2.6 \\
\hline$\ldots \ldots \ldots$ & 4.0 & 246.5 & 1.6 \\
\hline $1988 \ldots \ldots \ldots \ldots \ldots \ldots$ & 4.1 & 264.1 & 1.6 \\
\hline 1990 & 4.3 & 300.7 & 1.4 \\
\hline 1991 & 5.0 & 311.1 & 1.6 \\
\hline$\ldots \ldots \ldots \ldots$ & 4.3 & 327.6 & 1.3 \\
\hline $1993 \ldots \ldots \ldots \ldots \ldots$ & 4.6 & 353.3 & 1.3 \\
\hline
\end{tabular}

Sources: U.S. Bureau of the Census, Series GF/92-1, State Government Tax Collections: 1992, U.S. Government Printing Office, Washington, DC, 1994, and earlier issues, and U.S. Bureau of the Census, unpublished data; and The Book of the States, (Lexington, KY: Council of State Governments), 1994-95 and earlier issues. 
As energy severance tax receipts have declined, most of the energy-producing States have come to rely less on severance taxes as a major source of revenue. The top eight energy-producing States collected $\$ 5.8$ billion in energy severance taxes in 1985, 10.6 percent of their total tax receipts (Table 2). ${ }^{5}$ By 1993, they collected only $\$ 3.7$ billion, 4.3 percent of their total tax receipts (Figure 4).

Figure 3. U.S. Production of Oil, Natural Gas, and Coal

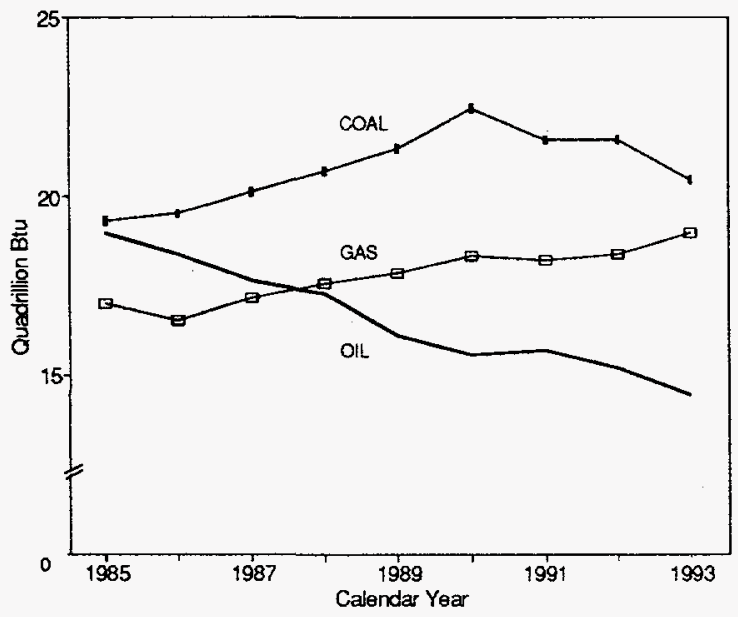

Source: Energy Information Administration, Annual Energy Review, 1993, DOE/EIA-0384(93) (Washington, DC, July 1994), Table 1.2
Figure 4. Energy Severance Tax Share of Taxes, Top 8 Energy-Producing States

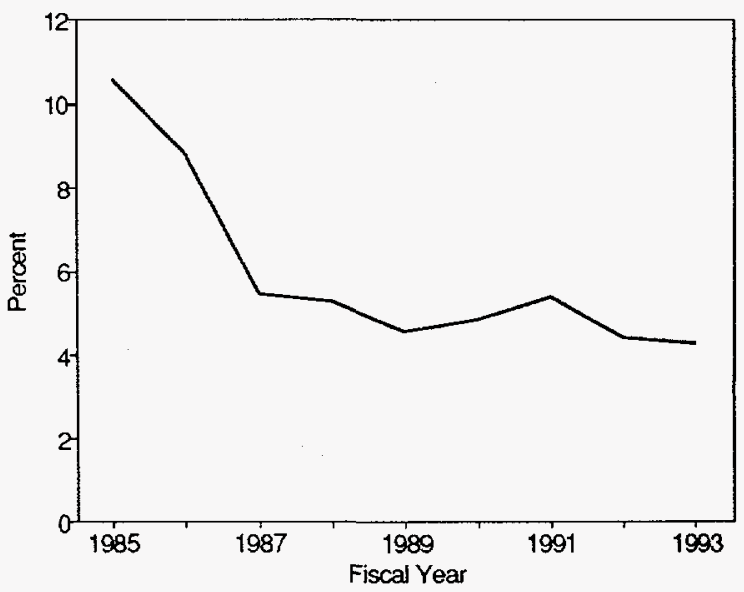

Note: The top eight energy producing states in rank order, are: Texas, Louisiana, Wyoming, Alaska, Kentucky, West Virginia, Oklahoma, and California.

Sources: U.S. Bureau of the Census, Series GF/92-1, State Government Tax Collections: 1992, U.S. Government Printing Office, Washington, DC, 1994, and earlier issues, and U.S. Bureau of the Census, unpublished data.

Table 2. State Government Severance Tax Receipts For Top 8 Energy-Producing States, Fiscal Years 1985-1993

\begin{tabular}{|c|c|c|c|c|}
\hline & Fiscal Year & $\begin{array}{c}\text { Energy } \\
\text { Severance Taxes } \\
\text { (billion dollars) }\end{array}$ & $\begin{array}{c}\text { Total } \\
\text { State Taxes } \\
\text { (billion dollars) }\end{array}$ & $\begin{array}{c}\text { Share of Total } \\
\text { State Taxes } \\
\text { (percent) }\end{array}$ \\
\hline 1985 & $\ldots \ldots \ldots \ldots \ldots \ldots$ & 5.8 & 54.9 & 10.6 \\
\hline 1986 & $\ldots \ldots \ldots \ldots \ldots \ldots$ & 5.0 & 56.5 & 8.8 \\
\hline 1987 & $\ldots \ldots \ldots \ldots \ldots \ldots$ & 3.3 & 60.3 & 5.4 \\
\hline 1988 & $\ldots \ldots \ldots \ldots \ldots \ldots$ & 3.3 & 62.4 & 5.3 \\
\hline 1989 & 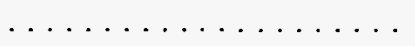 & 3.2 & 70.4 & 4.5 \\
\hline 1990 & $\ldots \ldots \ldots \ldots \ldots \ldots$ & 3.6 & 74.3 & 4.8 \\
\hline 1991 & $\ldots \ldots \ldots \ldots \ldots$ & 4.2 & 79.0 & 5.4 \\
\hline 1992 & $\ldots \ldots \ldots \ldots \ldots \ldots$ & 3.6 & 80.9 & 4.4 \\
\hline 1993 & $\ldots \ldots \ldots \ldots \ldots$ & 3.7 & 86.2 & 4.3 \\
\hline
\end{tabular}

Note: The top eight states in production of oil, gas, and coal (on a Btu basis) are in rank order: Texas, Louisiana, Wyoming, Alaska, Kentucky, West Virginia, Oklahoma, and California.

Sources: U.S. Bureau of the Census, Series GF/92-1, State Government Tax Collections: 1992, U.S. Government Printing Office, Washington, DC, 1994, and earlier issues, and U.S. Bureau of the Census, unpublished data; and The Book of the States, (Lexington, KY: Council of State Governments), 1994-95 and earlier issues.

${ }^{5}$ The top eight states in production of oil and gas (including production from Federal Outer Continental Shelf [OCS] areas) and coal on an energy-equivalent basis are (in rank order): Texas, Louisiana, Wyoming, Alaska, Kentucky, West Virginia, Oklahoma, and California. 


\section{Reliance on Oil and Gas Severance Taxes Decreases in 1990's}

Some oil and gas produced in the United States is not subject to State severance tax, because it is produced from Federal areas. State severance taxes apply only to energy production from areas under State jurisdiction. Thus, oil and gas production from Federal Outer Continental Shelf (OCS) waters off Alabama, California, Louisiana, and Texas are exempt from State severance taxes. ${ }^{6}$ However, these States also produce oil and gas from State offshore areas, and production from State offshore is subject to State severance tax.

Collections of oil and gas severance taxes on production under State jurisdiction decreased 38 percent from 1985 to 1993 , from $\$ 6.4$ billion to $\$ 4.0$ billion (Table 3). Over the same period, the effective rate of severance taxation (on a crude oil equivalent basis) decreased 31 percent, from $\$ 1.17$ to $\$ 0.81$ per barrel. ${ }^{7}$ The decline in oil and gas severance tax collections reflects the market prices and volumes of production, as the tax per barrel as a percent of price per barrel varied little, ranging from 5.9 percent in 1988, to 6.5 percent in 1986, 1991 and 1992.

Reliance on oil and gas severance taxes varies widely across the States. Of the top eight oil- and gas-producing States, California collects relatively minor amounts of oil and gas severance taxes, while Alaska depended on severance taxes for nearly 50 percent of State tax receipts in 1993 (Figure 5). Nationwide reliance on oil and gas severance taxes has decreased since the oil price collapse of 1986, when the decline in prices and production eroded the severance tax base (Figure 5). Severance tax receipts collected by the State of Texas, for example, fell by 46 percent from 1985 to 1993. The top eight States (except for Wyoming) were also successful in increasing the absolute level of tax receipts from sources other than oil and gas severance taxes. ${ }^{8}$

Table 3. State Government Severance Taxes for Oil and Natural Gas, Fiscal Years 1985-1993

\begin{tabular}{|c|c|c|c|c|c|}
\hline & Year & $\begin{array}{l}\text { Total Taxes } \\
\text { (billion dollars) }\end{array}$ & $\begin{array}{c}\text { Effective Tax } \\
\text { per Barrel } \\
\text { (dollars per barrel) }\end{array}$ & $\begin{array}{l}\text { Price per Barrel } \\
\text { (dollars per barrel) }\end{array}$ & $\begin{array}{c}\text { Effective Tax per } \\
\text { Barrel as a } \\
\text { Percent of Price }\end{array}$ \\
\hline 1986 & & 5.4 & 1.00 & 15.48 & 6.5 \\
\hline 1987 & 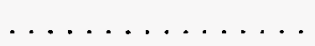 & 3.4 & 0.66 & 10.84 & 6.1 \\
\hline 1990 & $\ldots$ & 3.8 & 0.76 & 11.88 & 6.4 \\
\hline 1991 & $\ldots \ldots \ldots \ldots$ & 4.5 & 0.89 & 13.72 & 6.5 \\
\hline 1992 & $\ldots \ldots \ldots \ldots$ & 3.7 & 0.75 & 11.05 & 6.5 \\
\hline 1993 & $\ldots \ldots \ldots \ldots$ & 4.0 & 0.81 & 12.77 & 6.3 \\
\hline
\end{tabular}

Note: Natural gas is converted to barrels of crude oil equivalent on the basis of 0.178 barrels of oil per thousand cubic feet of gas.

Sources: Severance Taxes: U.S. Bureau of the Census, Series GF/92-1, State Government Tax Collections: 1992, U.S. Government Printing Office, Washington, DC, 1994, and earlier issues, and U.S. Bureau of the Census, unpublished data; The Book of the States, (Lexington, KY: Council of State Governments), 1994-95 and earlier issues. Energy Prices: Energy Information Administration, Historical Monthly Energy Review, 1973-1992, DOE/EIA-0035 (73-92) (Washington, DC, August 1994), Tables 9.1 and 9.11. Production: See notes to Table $A 3$ and $A 4$ in Appendix.

\footnotetext{
${ }^{6}$ In 1993, production of oil and gas (on a crude oil equivalent basis) from the Federal Outer Continental Shelf was about 22 percent of U.S. total oil and gas production. Source: Table A5 of this report, and Energy Information Administration, U.S. Crude Oil, Natural Gas, and Natural Gas Liquids Reserves 1993, DOE/EIA-0216(93) (Washington, DC, October 1994), p. 8.

'Production from the Federal Outer Continental Shelf (OCS) is excluded from fiscal year estimates of State oil and gas production.

${ }^{8}$ U.S. Bureau of the Census, Series GF/92-1, State Government Tax Collections: 1992, U.S. Government Printing Office, Washington, DC, 1994, and earlier issues, and U.S. Bureau of the Census, unpublished data.
} 
Figure 5. Reliance on Oil and Gas Severance Taxes, Selected States

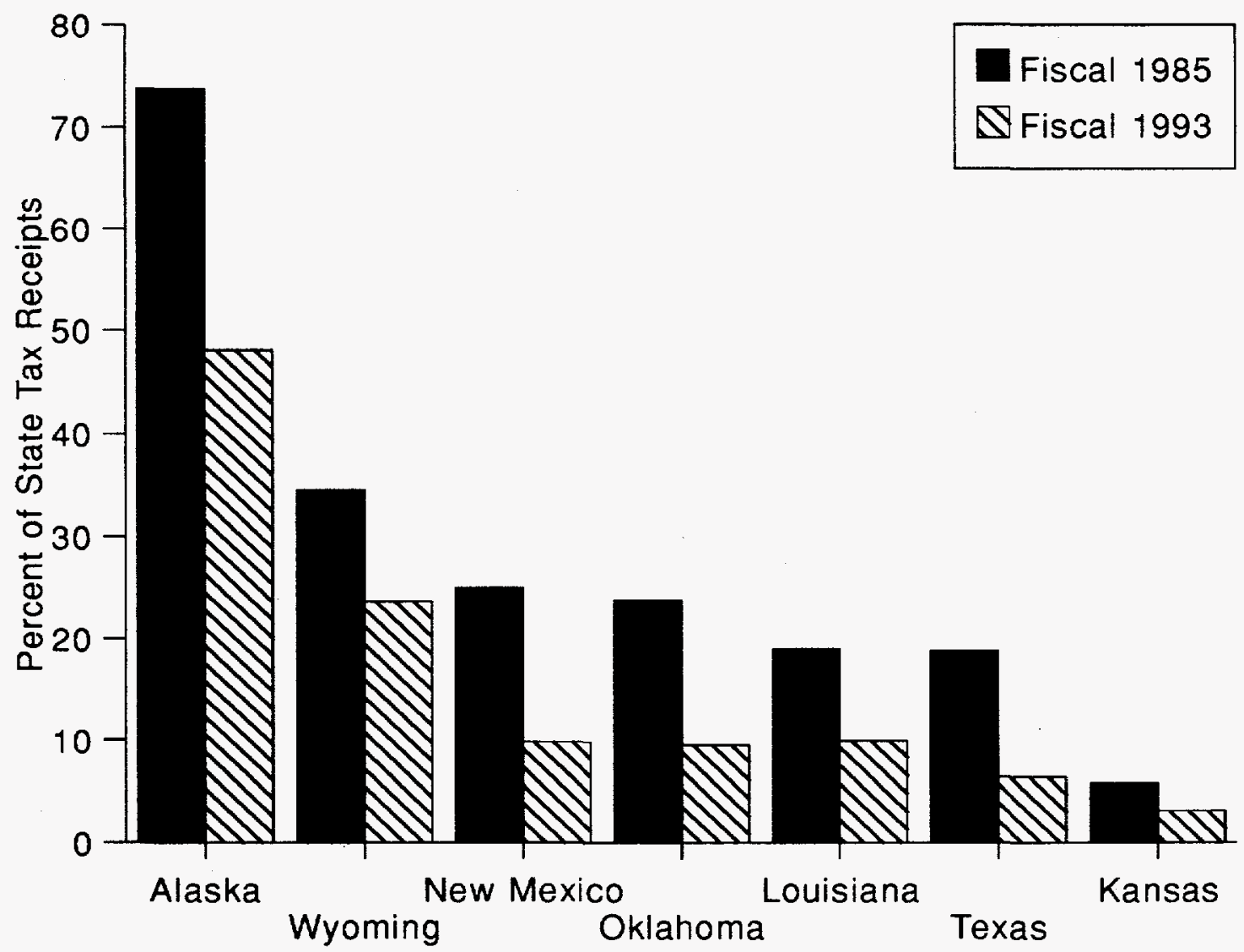

Source: U.S. Bureau of the Census, Series GF/92-1. State Government Tax Collections: 1992, U.S. Government Printing Office, Washington, DC, 1994, and earlier issues, and U.S. Bureau of the Census, unpublished data; The Book of the States, (Lexington, KY: Council of State Governments), 1994-1995 and earlier issues.

\section{Coal Severance Tax Receipts Decline in the 1980's, Recover in the 1990's}

State receipts of coal severance taxes declined by 18 percent during the late 1980 's, from $\$ 619$ million in fiscal 1985 to $\$ 507$ million in fiscal 1989 (Table 4 and Figure 6). Coal production increased steadily during this period (Figure 3 ) and coal prices declined only slightly (Figure 2), indicating that the decline in receipts came from policy changes made by the coal-producing States. The top three coal-producing States (Wyoming, West Virginia, and Kentucky) all reduced their coal severance tax rates from 1985 to 1989 (Figure 7). ${ }^{9}$ Wyoming, the largest and fastest-growing coal producer, reduced its effective tax rate most dramatically, by 45 percent, from $\$ 0.92$ to $\$ 0.50$ per short ton.

'Wyoming (at 210 million short tons), Kentucky (at 156 million short tons), and West Virginia (at 131 million short tons) mined over one-half of the 945 million short tons produced in the United States in calendar year 1993. The fourth-largest producer, Pennsylvania, produced 60 million short tons in 1993, less than half of West Virginia's production level. The remaining top 10 coal producers in 1993 were Texas, Illinois, Virginia, Montana, North Dakota, and Indiana. Source: Energy Information Administration, Coal Industry Annual 1993, DOE/EIA-0584(93) (Washington, DC, December 1994), p. 4. 
Figure 6. Coal Severance Tax Receipts

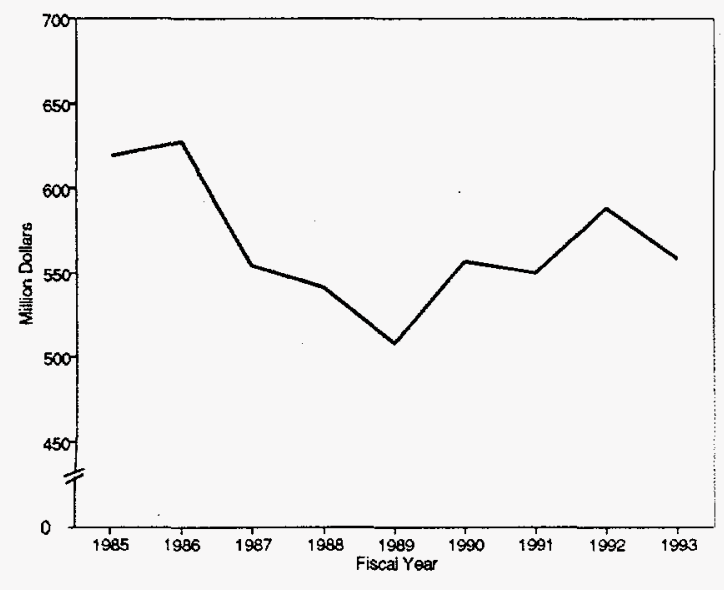

Source: U.S. Bureau of the Census, Series GF/92-1, State Government Tax Collections: 1992, U.S. Government Printing Office, Washington, DC, 1994, and earlier issues, and U.S. Bureau of the Census, unpublished data.
Figure 7. Effective Coal Severance Tax Rates, Top Three Coal-Producing States

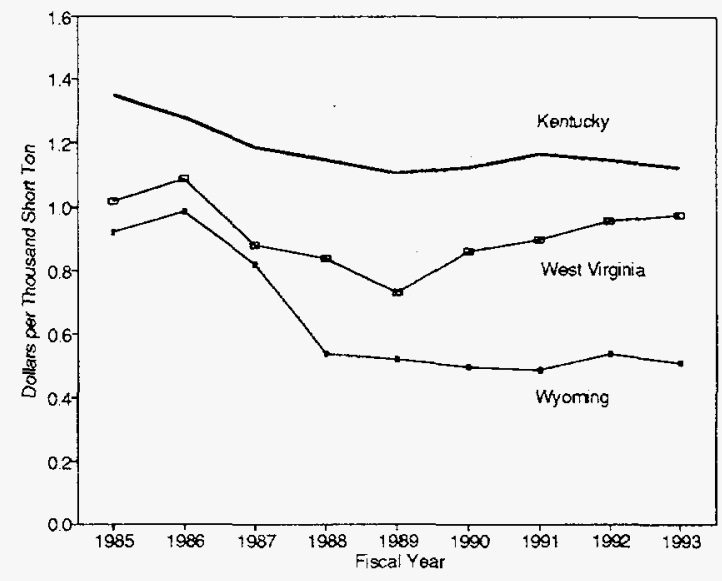

Sources: Coal Severance Taxes: U.S. Bureau of the Census, Series GF/92-1, State Government Tax Collections: 1992, U.S Government Printing Office, Washington, DC, 1994, and earlier issues, and U.S. Bureau of the Census, unpublished data. Coal Production: Energy Information Administration, Form ElA-74, "Coal Production Report."

Table 4. State Government Severance Taxes for Coal, Fiscal Years 1985-1993

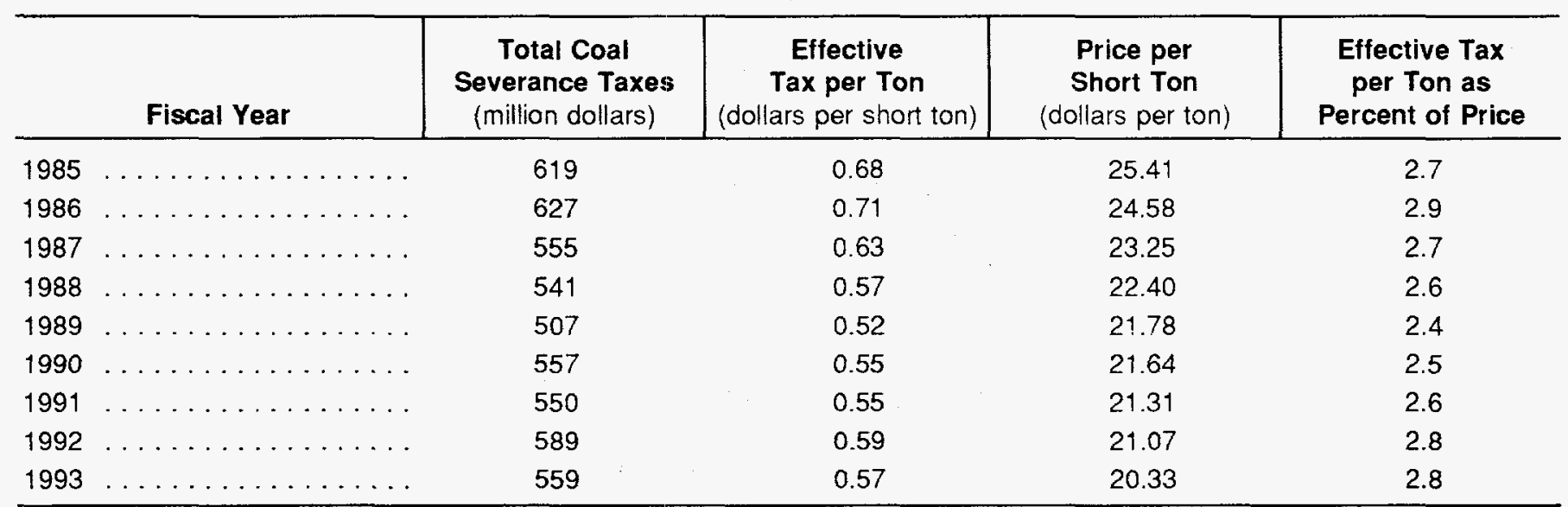

Sources: Coal Severance Taxes: U.S. Bureau of the Census, Series GF/92-1, State Government Tax Collections: 1992, U.S. Government Printing Office, Washington, DC, 1994, and earlier issues, and U.S. Bureau of the Census, unpublished data; Coal Production: Energy Information Administration, Form EIA-74, "Coal Production Report"; Coal Prices: Energy Information Administration, Coal Industry Annual, DOE/ElA-0584(93) (Washington, DC, December 1994), p. 147, and Energy Information Administration, Coal Production, DOE/EIA-0118, 1992 and earlier years.

Beginning in 1990, the major coal-producing States either increased (West Virginia) or stabilized (Kentucky and Wyoming) their severance tax rates (Figure 7). Combined with the steady decline in coal prices, this policy has resulted in a slight increase in the share of severance taxes in the price of coal, from 2.4 percent in 1989 to 2.8 percent in 1993 (Table 4). 
Coal severance taxes accounted for an average of 0.2 percent of all State tax receipts in the United States in 1993, but reliance on coal severance taxes varied widely across the producing States. Of the top 10) coal-producing States in 1993, Texas, Pennsylvania, Illinois, Virginia, and Indiana levied zero or negligible coal severance taxes at the State level. However, the top three producing States still rely on coal severance taxes for a portion of State funds, as do North Dakota and Montana (Figure 8).

Although still substantial for some States, this reliance on coal tax receipts has generally declined since 1985 (Figure 8), due mainly to growth in other sources of revenue. For example, West Virginia and Kentucky have increased State funds from taxes other than coal severance taxes by 26 and 45 percent, respectively, between 1985 and 1993.

Figure 8. Reliance on Coal Severance Taxes, Selected States

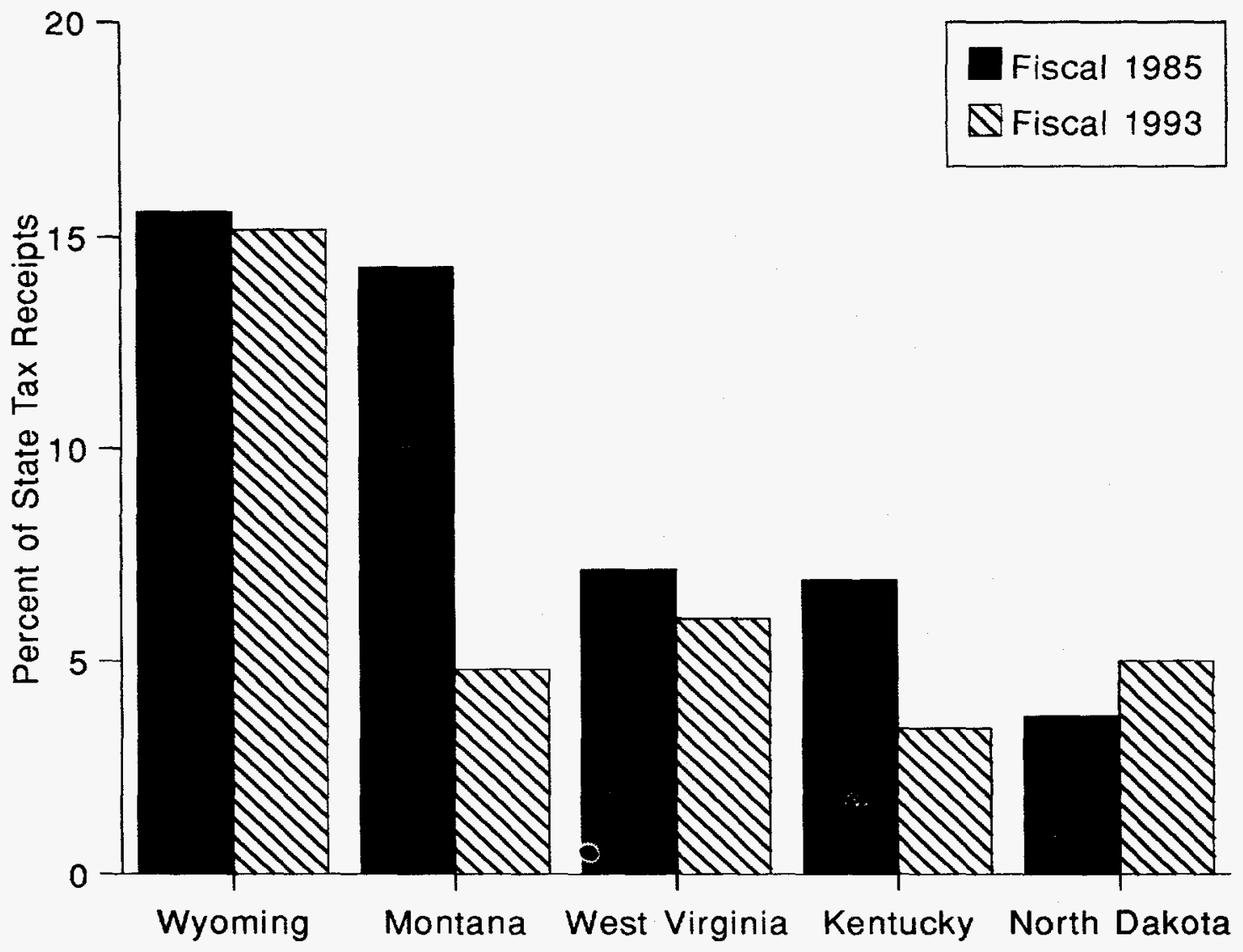

Source: U.S. Bureau of the Census, Series GF/92-1, State Government Tax Collections: 1992, U.S. Government Printing Office, Washington, DC, 1994, and earlier issues, and U.S. Bureau of the Census, unpublished data. 


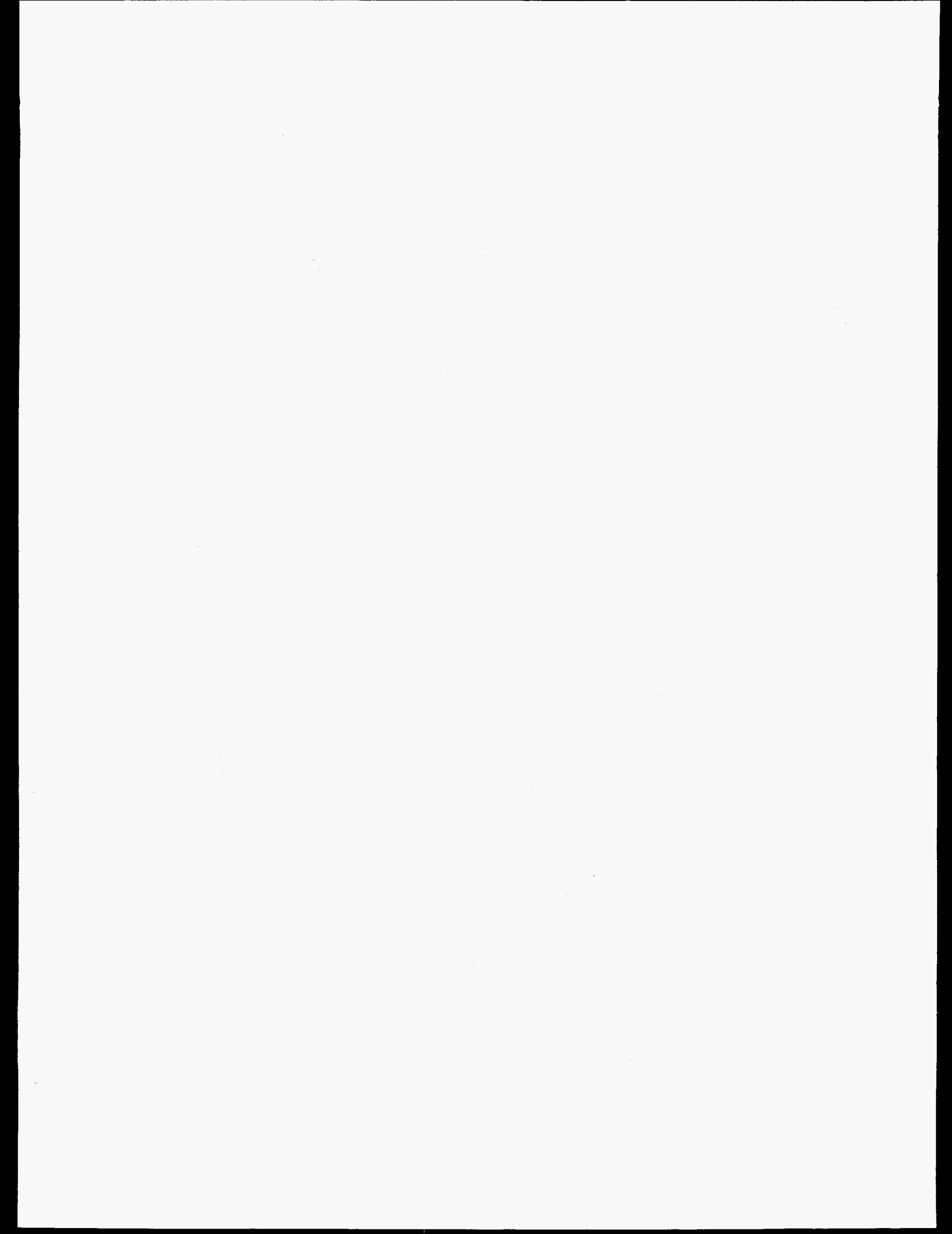




\section{Appendix: Methodology and Data Sources}

\section{Energy Production under State Jurisdiction}

State severance taxes apply only to energy production from areas under State jurisdiction. Thus, oil and gas production from Federal Outer Continental Shelf (OCS) waters off Alabama, California, Louisiana, and Texas are exempt from State severance tax. In this report, production from the OCS is excluded from fiscal year estimates of State energy production.

\section{Evaluating and Adjusting State Tax Receipt Data}

The primary source of data on severance tax receipts used in this study was the U.S. Bureau of the Census. ${ }^{10}$ Taxes on energy collected by county or city governments are not included. Reporting and classification of severance taxes is at the discretion of each State. Information from the Council of State Governments, The Book of the States, 1994-1995 and earlier editions, was used for detailed definitions of categories of severance taxes, helping to identify oil and gas severance taxes as well as coal severance taxes. For example, an adjustment was made for West Virginia, which transformed its "Business and Occupation" taxes on oil, gas, and coal producers into a severance tax in fiscal 1988. The West Virginia Department of Tax and Revenue provided a series of de facto severance taxes for 1985-1987. Similarly, coal severance tax receipts data for New Mexico were supplied by the New Mexico Taxation and Revenue Department. Consistency of the adjustments was confirmed by comparing results in overlapping years (1985-1987) to data reported in Energy Information Administration, Energy Severance Taxes, 1972-1987, DOE/EIA-0519 (Washington, DC, August 1988).

\section{Establishing Consistent Yearly Data}

State tax revenues are reported by fiscal year, rather than by calendar year. Further, there are four different fiscal year start dates that States employ, with the majority of States beginning their fiscal years on July 1st of the previous calendar year (see below). For example, fiscal 1985 began on July 1, 1984, and ended on June 30, 1985, for 46 States. ${ }^{11}$ Data for the United States as a whole presented in this report as fiscal year totals reflect the mix in fiscal years across the States.

\begin{tabular}{ll} 
State Fiscal Years & \\
\hline April 1 - March 31 & New York \\
September 1 - August 31 & Texas \\
October $1-$ September 30 & Alabama, Michigan \\
July 1 - June 30 & All Others \\
\hline
\end{tabular}

\footnotetext{
${ }^{10}$ U.S. Bureau of the Census, Series GF/92-1, State Gozernment Tax Collections: 1992, U.S. Government Printing Office, Washington, DC, 1994, and earlier issues, and U.S. Bureau of the Census, unpublished data. Unpublished data from the Bureau of the Census is available on the Internet, World Wide Web, http://www.census.gov80/ftp/pub/govs/www/state.html.

${ }^{11}$ The Book of the States, (Lexington, KY: Council of State Governments), 1994-1995 and earlier issues.
} 
The information on receipts of energy severance taxes is available on a fiscal year basis. ${ }^{12}$ To analyze severance taxes relative to the production of energy, production data (available on a calendar year or monthly basis), must be adjusted to correspond to each State's fiscal year. In cases where monthly data were unavailable, fiscal years were approximated by averaging the annual values for two consecutive calendar years. All data on production of oil, gas, and coal are from the Energy Information Administration, and sources are referenced in the Appendix Tables.

\section{Calculating Effective Tax Rates}

The effective rate of severance taxation was arrived at by dividing fiscal year tax receipts by fiscal year energy production. The effective rates of taxation for petroleum and coal do not necessarily equal the legislated rates of taxation, because legislation often specifies exceptions and exemptions. However, effective tax rates are useful in comparing the overall results of tax policy across States and over time, which is the intent of this report.

\footnotetext{
${ }^{12}$ U.S. Bureau of the Census, Series GF/92-1, State Government Tax Collections: 1992, U.S. Government Printing Office, Washington, DC, 1994, and earlier issues, and U.S. Bureau of the Census, unpublished data.
} 
Appendix Tables 


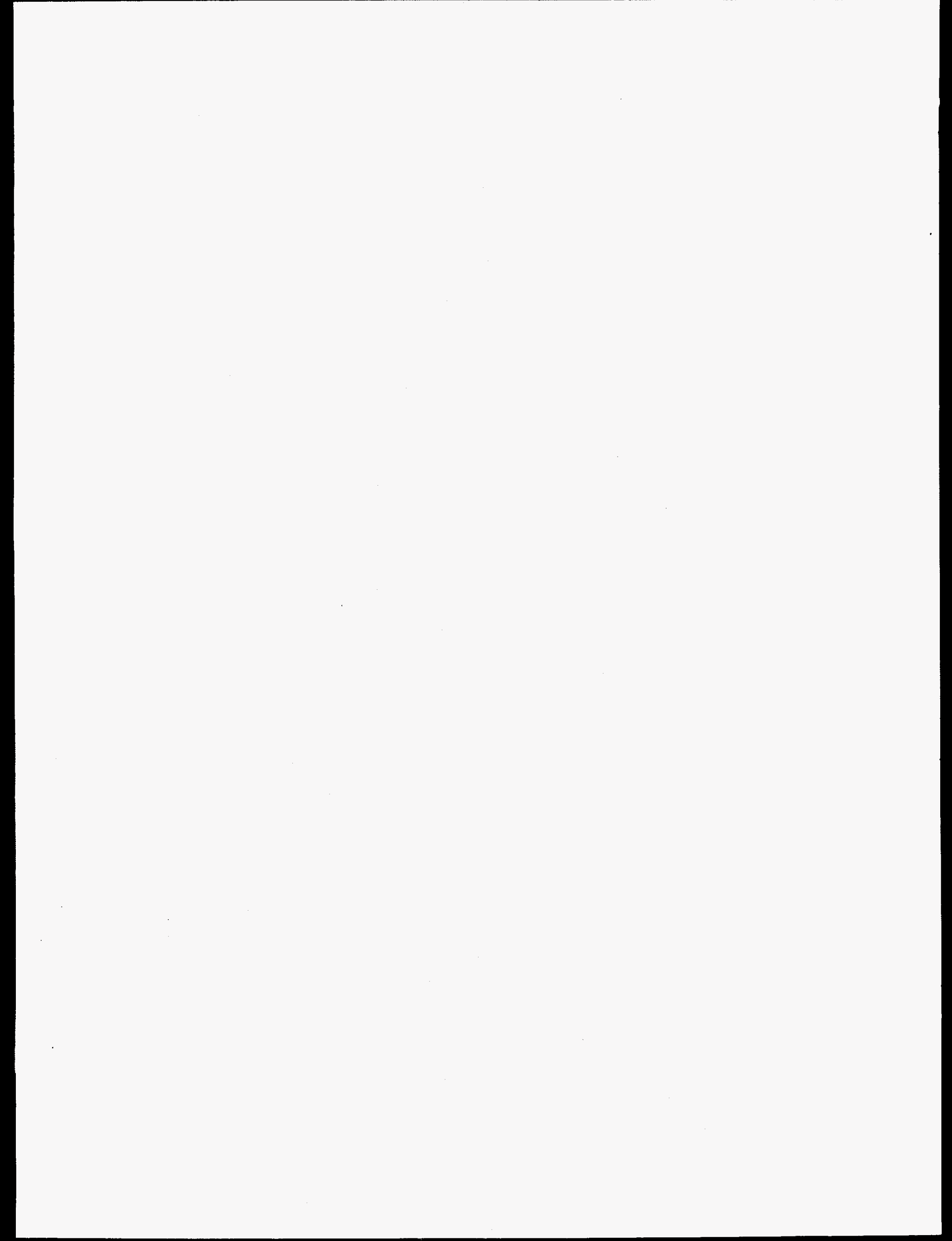


Table A1. State Government Crude Oil and Natural Gas Severance Tax Receipts, Fiscal Years 1985-1993 (Thousand Dollars)

\begin{tabular}{|c|c|c|c|c|c|c|c|c|c|}
\hline State & 1985 & 1986 & 1987 & 1988 & 1989 & 1990 & 1991 & 1992 & 1993 \\
\hline Alaska & $1,389,262$ & $1,432,911$ & 666,870 & 818,655 & 698,850 & $1,076,880$ & $1,256,781$ & $1,113,080$ & $1,072,079$ \\
\hline Arkansas & 23,025 & 19,042 & 11,787 & 12,711 & 11,048 & 12,015 & 13,321 & 11,389 & 11,578 \\
\hline California & 6,384 & 7,238 & 7,399 & 6,938 & 8,272 & 8,266 & 9,361 & 9,170 & 8,643 \\
\hline Colorado & 19,105 & 12,546 & 5,564 & 7,272 & 7,377 & 8,522 & 15,600 & 10,400 & 22,813 \\
\hline Indiana & 1,518 & 1,253 & 556 & 675 & 987 & 756 & 803 & 762 & 692 \\
\hline Kansas & 111,373 & 101,342 & 62,516 & 80,777 & 79,723 & 86,620 & 99,590 & 88,789 & 102,685 \\
\hline Kentucky & 14,790 & 24,418 & 9,727 & 14,960 & 10,675 & 11,764 & 13,755 & 10,913 & 12,263 \\
\hline Louisiana & 731,757 & 608,818 & 439,236 & 462.704 & 397,375 & 414,888 & 564,597 & 474,614 & 433,994 \\
\hline Michigan & 75,729 & $.52,821$ & 48,344 & 43,581 & 40,541 & 45,570 & 48,895 & 41,331 & 40,069 \\
\hline New Mexico & 360,659 & 336,408 & 206,951 & 260,620 & 218,672 & 253,282 & 220,974 & 203,041 & 270,907 \\
\hline North Dakota & 150,921 & 120,162 & 69,475 & 72,507 & 56.491 & 58,939 & 85,777 & 121,140 & 86,998 \\
\hline Ohio & 5,115 & 5,437 & 4,858 & 4,680 & 4,325 & 4,207 & 3,913 & 3,883 & 3,845 \\
\hline Oklahoma & 708,816 & 571,375 & 370,178 & 386,680 & 367,145 & 395,292 & 415,528 & 354,988 & 394,134 \\
\hline South Dakota & 865 & NA & 0 & 1,243 & 1,023 & 1,284 & 1,634 & 1,322 & 1,253 \\
\hline Tennessee & 1,092 & 784 & 351 & 400 & 327 & 352 & 404 & 380 & 356 \\
\hline Texas & $2,171,330$ & $1,547,926$ & $1,178,051$ & $1,055,564$ & $1,168,019$ & $1,084,227$ & $1,351,773$ & $1,009,878$ & $1,175,185$ \\
\hline Utah & 48,592 & 42,881 & 20,793 & 25,513 & 25,637 & 24,707 & 23,764 & 11,747 & 13,246 \\
\hline West Virginia & 50,778 & 55,252 & 40,133 & 29,553 & 24,967 & 23,206 & 20,823 & 17,464 & 18,674 \\
\hline Wyoming & 278,348 & 255,555 & 144,259 & 146,197 & 142,617 & 164,916 & 173,121 & 145,622 & 156,902 \\
\hline
\end{tabular}

Sources: U.S. Bureau of the Census, Series GF/92-1, State Government Tax Collections: 1992, U.S. Government Printing Office, Washington, DC, 1994, and earlier issues, and U.S. Bureau of the Census, unpublished data; The Book of the States (Lexington, KY: Council of State Governments), 1994-95 and earlier issues. 
Table A2. State Government Coal Severance Tax Receipts, Fiscal Years 1985-1993 (Thousand Dollars)

\begin{tabular}{|c|c|c|c|c|c|c|c|c|c|}
\hline Alabama $\ldots \ldots \ldots$ & 3,544 & 8,426 & 7.991 & 8,731 & 8,542 & 9,004 & 8,855 & 8,331 & 8,056 \\
\hline Colorado . . . . . . . . & 8,869 & 9,068 & 3,784 & 7,814 & 6,043 & 5,360 & 5,890 & 5,300 & 8,261 \\
\hline$\ldots \ldots \ldots$ & 427 & 679 & 1,004 & 1,025 & 0 & 0 & 29 & 0 & 0 \\
\hline Kentucky ......... & 207,363 & 198,526 & 186,347 & 189,244 & 180,604 & 195,496 & 191,037 & 185,467 & 180,118 \\
\hline Montana . . . . . . . . . & 91,749 & 84,217 & 76,547 & 84,638 & 58,566 & 67,871 & 50,458 & 54,114 & 38,182 \\
\hline North Dakota & 25,357 & 26,809 & 26,323 & 20,750 & 23,008 & 20,637 & 22,238 & 41,626 & 44,037 \\
\hline Ohio & 1,584 & 1,873 & 2,086 & 3,081 & 2,864 & 2,967 & 2,931 & 2,623 & 2,602 \\
\hline Tennessee & 1,727 & 1,537 & 1.230 & 1,420 & 1,261 & 1,185 & 1,043 & 819 & 659 \\
\hline West Virginia & 131,910 & 142,722 & 113,388 & 117,062 & 111,988 & 137,444 & 150,103 & 160,922 & 148,066 \\
\hline Wyoming & 125,683 & 131,737 & 115,476 & 84,075 & 89,124 & 89,108 & 93,419 & 103,815 & 100,349 \\
\hline
\end{tabular}

Sources: U.S. Bureau of the Census, Series GF/92-1, State Government Tax Collections: 1992, U.S. Government Printing Office, Washington, DC, 1994, and earlier issues, and U.S. Bureau of the Census, unpublished data; The Book of the States (Lexington, KY: Council of State Governments), 1994-95 and earlier issues. 
Table A3. Production of Oil Under State Jurisdiction, Including Lease Condensate, Fiscal Years 1985-1993 (Thousand Barrels) $^{\mathrm{a}}$

\begin{tabular}{|c|c|c|c|c|c|c|c|c|c|}
\hline State & 1985 & 1986 & 1987 & 1988 & 1989 & 1990 & 1991 & 1992 & 1993 \\
\hline Alabama & 20,878 & 21,927 & 20,391 & 20,587 & 20,614 & 19,030 & 18,473 & 19,179 & 18,515 \\
\hline Alaska & 648,802 & 677,077 & 695,273 & 731,058 & 710,191 & 665,066 & 655,338 & 644,346 & 598,119 \\
\hline Arizona & 185 & 179 & 137 & 123 & 122 & 138 & 117 & 99 & 85 \\
\hline Arkansas . . . . . & 18,746 & 18,011 & 14,733 & 14,243 & 12,109 & 11,069 & 11,076 & 10,639 & 10,250 \\
\hline California & 386,570 & 394,981 & 365,151 & 363,875 & 342,073 & 325,270 & 320,305 & 313,959 & 296,871 \\
\hline Colorado & 29,530 & 30,049 & 28,626 & 31,170 & 32,390 & 30,746 & 31,126 & 31,170 & 30,135 \\
\hline Florida & 12,957 & 10,607 & 8,273 & 8,241 & 7,366 & 6,813 & 4,644 & 5,291 & 5,412 \\
\hline Illinois & 29,585 & 30,406 & 24,524 & 23,595 & 21,268 & 20,106 & 19,265 & 19,352 & 18,252 \\
\hline Indiana & 5,363 & 4,978 & 4,367 & 3,881 & 3,442 & 3,130 & 2,970 & 3,017 & 2,876 \\
\hline Kansas & 75,472 & 73,869 & 61,413 & 60,497 & 56,892 & 54,599 & 57,542 & 55,373 & 50,779 \\
\hline Kentucky & 7,732 & 7,498 & 5,879 & 5,624 & 5,588 & 5,161 & 5,451 & 5,505 & 5,275 \\
\hline Louisiana & 186,269 & 183,770 & 178,128 & 171,350 & 158,759 & 148,372 & 148,493 & 146,061 & 140,176 \\
\hline Michigan & 28,373 & 26,881 & 25,630 & 24,843 & 22,313 & 20,489 & 18,921 & 16,373 & 14,484 \\
\hline Mississippi & 31,584 & 30,586 & 29,118 & 27,864 & 28,246 & 27,903 & 27,414 & 26,242 & 24,062 \\
\hline Missouri & 258 & 223 & 96 & 162 & 142 & 144 & 142 & 155 & 134 \\
\hline Montana & 29,903 & 28,862 & 25,705 & 24,415 & 22,052 & 20,260 & 19,774 & 19,060 & 17,842 \\
\hline Nebraska & 6,709 & 7,165 & 6,536 & 5,890 & 6,285 & 5,975 & 5,842 & 5,767 & 5,130 \\
\hline Nevada & 2,686 & 3,140 & 2,923 & 3,139 & 3,228 & 3,602 & 3,982 & 3,130 & 3,194 \\
\hline New Mexico & 79,557 & 77,966 & 72,534 & 72,512 & 70,041 & 67,785 & 69,685 & 70,734 & 69,032 \\
\hline New York & 959 & 959 & 796 & 641 & 530 & 438 & 420 & 413 & 380 \\
\hline North Dakota & 52,256 & 48,918 & 43,009 & 40,251 & 37,628 & 36,796 & 36,776 & 34,294 & 31,777 \\
\hline Ohio & 15,174 & 14,220 & 12,957 & 12,055 & 11,014 & 9,962 & 9,469 & 9,229 & 8,658 \\
\hline Oklahoma & 164,951 & 160,206 & 138,410 & 132,847 & 122,840 & 114,345 & 110,894 & 104,668 & 99,059 \\
\hline Pennsylvania & 4,560 & 4,322 & 3,582 & 3,080 & 2,738 & 2,647 & 2,511 & 2,310 & 2,162 \\
\hline South Dakota & 1,504 & 1,582 & 1,613 & 1,680 & 1,606 & 1,633 & 1,665 & 1,620 & 1,516 \\
\hline Tennessee & 864 & 703 & 612 & 616 & 577 & 516 & 482 & 521 & 441 \\
\hline Texas .. & 873,577 & 857,447 & 781,401 & 751,333 & 710,771 & 676,663 & 689,733 & 665,698 & 635,919 \\
\hline Utah $\ldots$ & 38,654 & 41,625 & 36,786 & 34,900 & 30,102 & 28,291 & 26,463 & 23,866 & 22,955 \\
\hline Virginia & 29 & 21 & 17 & 23 & 23 & 18 & 12 & 12 & 13 \\
\hline West Virginia & 3,623 & 3,406 & 2,934 & 2,770 & 2,427 & 2,163 & 2,055 & 1,984 & 2,080 \\
\hline Wyoming & 127,411 & 126,879 & 116,310 & 116,524 & 111,192 & 106,131 & 101,882 & 98.755 & 91,880 \\
\hline \multicolumn{10}{|l|}{ Total Under } \\
\hline State Jurisdiction & $2,884,721$ & $2,888,463$ & $2,707,865$ & $2,689,788$ & $2,554,570$ & $2,415,260$ & $2,402,922$ & $2,338,823$ & $2,207,466$ \\
\hline
\end{tabular}

aproduction excludes Federal Outer Continental Shelf (OCS).

Note: Totals may not equal sum of components due to independent rounding.

Sources: Energy Information Administration, Petroleum Supply Annual, Vol.1, DOE/EIA-0340 (Washington, DC), various issues. 
Table A4. Marketed Production of Natural Gas (Wet) Under State Jurisdiction, Fiscal Years 1985-1993 (Million Cubic Feet) $^{\mathrm{a}}$

\begin{tabular}{|c|c|c|c|c|c|c|c|c|c|}
\hline State & 1985 & 1986 & 1987 & 1988 & 1989 & 1990 & 1991 & 1992 & 1993 \\
\hline Alabama ..... & 109,107 & 105,818 & 114,825 & 125,532 & 133,235 & 129,482 & 154,500 & 312,769 & 366,835 \\
\hline Alaska .... & 313,291 & 310,696 & 330,643 & 369,569 & 386,899 & 395,432 & 421,367 & 447,240 & 434,730 \\
\hline California ..... & 437,206 & 435,373 & 394,315 & 366,154 & 342,110 & 316,680 & 326,215 & 338,916 & 286,961 \\
\hline Colorado ...... & 175,634 & 171,370 & 156,052 & 187,020 & 196,872 & 229,023 & 261,904 & 303,564 & 362,155 \\
\hline Florida . . . . . . . & 11,806 & 9,853 & 8,105 & 8,225 & 7,176 & 7.442 & 4,690 & 6,354 & 6,984 \\
\hline Kansas ...... & 458,102 & 539,385 & 491,426 & 555,495 & 590,177 & 579,981 & 599,385 & 623,849 & 690,141 \\
\hline Louisiana ...... & $2,027,151$ & $1,765,442$ & $1,844,841$ & $1,884,239$ & $1,832,440$ & $1,612,823$ & $1,715,707$ & $1,683,553$ & $1,539,334$ \\
\hline Michigan & 136,367 & 126,106 & 143,118 & 147,573 & 152,300 & 169,381 & 190,081 & 191,423 & 212,431 \\
\hline Mississippi & 151,023 & 139,988 & 144,493 & 131,350 & 113,424 & 94,846 & 101,851 & 100,365 & 87,872 \\
\hline Montana & 51,118 & 49,088 & 46,426 & 47,539 & 53,405 & 49,993 & 53,435 & 52,552 & 54,416 \\
\hline New Mexico .... & 970,198 & 804,352 & 709,096 & 867,921 & 785,380 & 914,848 & $1,009,998$ & $1,108,269$ & $1,370,311$ \\
\hline North Dakota ... & 71,583 & 61,939 & 62,531 & 59,147 & 53,714 & 51,876 & 52,585 & 54,202 & 57,206 \\
\hline Oklahoma .... & $2,054,144$ & $1,949,273$ & $2,022,506$ & $2,113,997$ & $2,190,965$ & $2,273,463$ & $2,212,985$ & $2,076,326$ & $2,020,215$ \\
\hline Texas $\ldots . .$. & $5,143,133$ & $5,257,259$ & $4,972,542$ & $5,035,650$ & $4,977,488$ & $4,923,595$ & $4,829,803$ & $4,892,835$ & $4,992,523$ \\
\hline Utah $\ldots \ldots \ldots$ & 78,327 & 87,777 & 84,311 & 100,916 & 106,991 & 134,268 & 143,483 & 147,595 & 213,536 \\
\hline Wyoming & 463,796 & 396,362 & 486,687 & 480,005 & 583,249 & 685,867 & 769,659 & 772,643 & 855,705 \\
\hline Other States . . . . & 796,676 & 749,741 & 782,636 & 727,068 & 815,456 & 808,581 & 810,459 & 722,063 & 763,165 \\
\hline \multicolumn{10}{|l|}{ Total Under State } \\
\hline Jurisdiction . . . . & $13,448,662$ & $12,959,822$ & $12,794,554$ & $13,207,400$ & $13,321,280$ & $13,377,581$ & $13,658,107$ & $13,834,517$ & $14,314,521$ \\
\hline
\end{tabular}

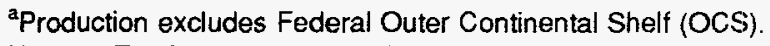

Notes: Totals may not equal sum of components due to independent rounding. Federal ocs production on a fiscal year basis was estimated on the basis of the arithmetic average of production in each appropriate calendar year. Federal OCS production is subtracted from total State production in Texas, Louisiana, and California to arrive at production under State jurisdiction. A small amount of Federal OCS production from Federal offshore Alabama is included in Federal offshore Louisiana.

Sources: Marketed Production by State: Energy Information Administration, Form ElA-627, and Energy Information Administration, Natural Gas Monthly, DOE/EIA-0130, (Washington, DC), various issues. Federal OCS Wel Natural Gas Production: Energy Information Administration, U.S. Crude Oil Natural Gas and Natural Gas Liquids Reserves 1993, DOE/EIA-0216 (Washington DC), 1986-1993; Estimate for Federal OCS production in 1985 and 1986 are based on Energy Information Administration, Natural Gas Annual 1988, DOE/ElA-0131(88) (Washington, DC, October 1989), Table 4. 
Table A5. Production of Oil and Gas Under State Jurisdiction, Fiscal Years 1985-1993 (Thousand COE Barrels)

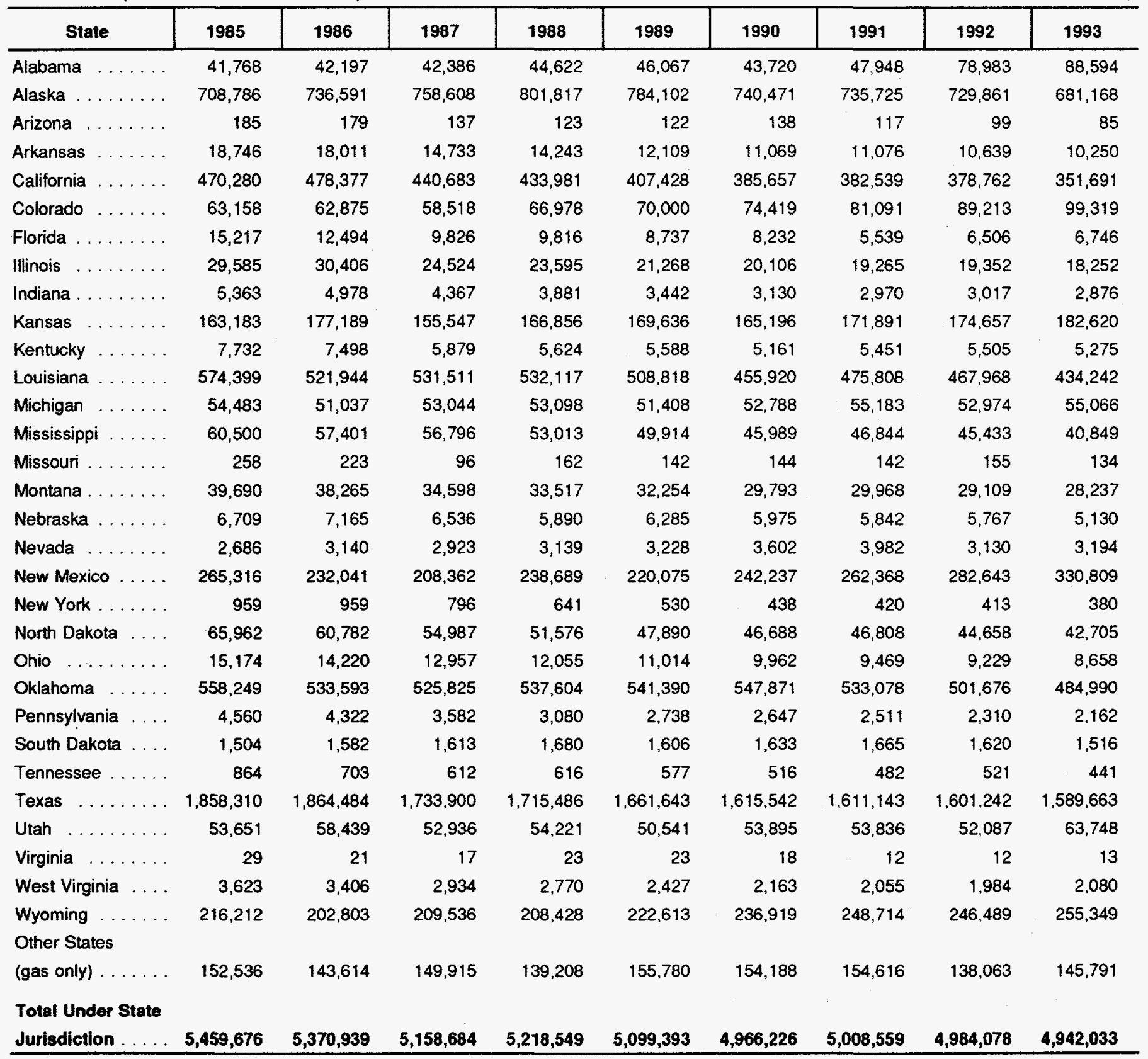

COE $=$ Crude oil equivalent barrels.

Notes: Production excludes Federal Outer Continental Shelf (OCS). Totals may not equal sum of components due to independent rounding. Wet natural gas is converted to crude oil equivalent barrels (COE), on the basis of an approximate heat content ranging from 1,112 Btu per cubic foot in 1985 to 1,106 Btu per cubic foot in 1993.

Source: See footnotes to Appendix Tables A3, A4. 
Table A6. Coal Production, Fiscal Years 1985-1993 (Thousand Short Tons)

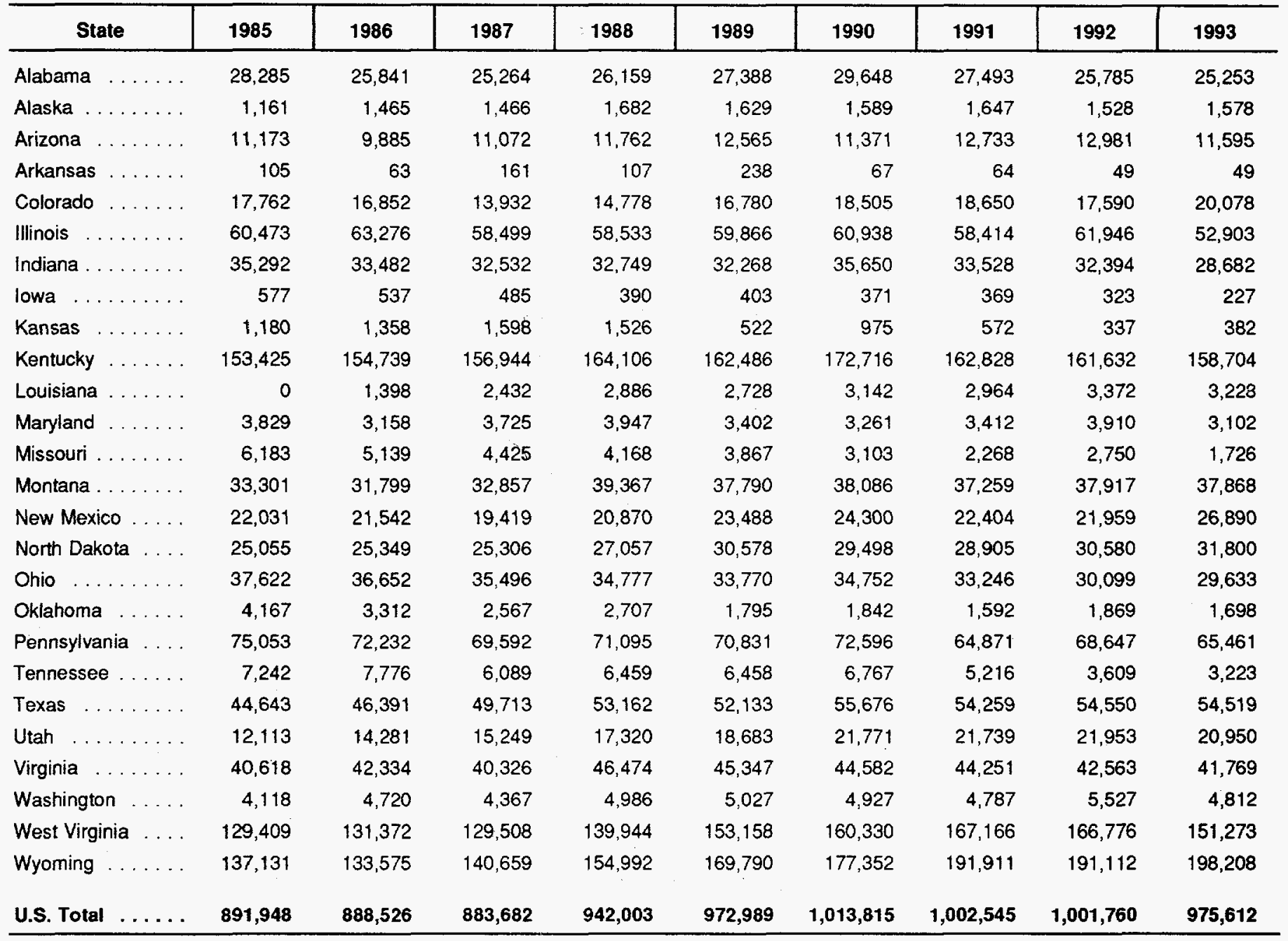

Note: Totals may not equal sum of components due to independent rounding.

Sources: Energy Information Administration, form EIA-7A, "Coal Production Report;" State Mining Agency Coal Production Reports; and/or US Department of Labor, Mine Safety and Health Administration, Form 7000-2, "Quarterly Mine Employment and Coal Production Report." 
Table A7. State Government Crude Oil and Natural Gas Severance Tax Receipts, Fiscal Years 1972-1984 (Thousand Dollars)

\begin{tabular}{|c|c|c|c|c|c|c|c|c|c|c|c|c|c|}
\hline State & 1972 & 1973 & 1974 & 1975 & 1976 & 1977 & 1978 & 1979 & 1980 & 1981 & 1982 & 1983 & 1984 \\
\hline Alabama & 2,098 & 2,884 & 5,426 & 8,090 & 9,229 & 11,529 & 15,482 & 17,310 & 30,019 & 55,757 & 57,873 & 72,275 & 114,085 \\
\hline Alaska ...... & 12,124 & 11,469 & 14,763 & 26,619 & 27,978 & 23,758 & 107,715 & 173,685 & 506,469 & $1,170,180$ & $1,571,553$ & $1,494,034$ & $1,393,039$ \\
\hline Arkansas .... & 3,871 & 3,840 & 5,396 & 6,287 & 7,798 & 9,248 & 10,632 & 10,727 & 16,248 & 24,711 & 26,816 & 25,490 & 24,072 \\
\hline California .... & 1,554 & 1,407 & 1,661 & 2,331 & 2,334 & 1,530 & 2,313 & 4,188 & 3,535 & 4,395 & 5,303 & 5,339 & 4,667 \\
\hline Colorado & 524 & 795 & 1,063 & 2,315 & 4,313 & 2,244 & 4,726 & 7,863 & 8,742 & 17,854 & 34,393 & 24,040 & 18,827 \\
\hline Florida & 2,250 & 4,910 & 12,177 & 20,214 & 26,371 & 26,439 & 42,768 & 49,307 & 57,318 & 95,240 & 79,388 & 78,245 & 71,599 \\
\hline Indiana ... & 221 & 203 & 315 & 475 & 508 & 580 & 649 & 673 & 1,582 & 1,811 & 1,780 & 1,616 & 1,521 \\
\hline Kansas & 687 & 711 & 704 & 700 & 785 & 816 & 841 & 1,097 & 1,100 & 1,007 & 1,013 & 2,339 & 116,585 \\
\hline Kentucky & 174 & 159 & 243 & 349 & 418 & 408 & 395 & 404 & 876 & 12,342 & 13,696 & 14,270 & 13,377 \\
\hline Louisiana & 236,485 & 259,455 & 380,768 & 539,571 & 507,140 & 485,339 & 466,346 & 458,009 & 513,151 & 803,147 & 971,678 & 859,930 & 803,183 \\
\hline Michigan & 967 & 1,076 & 2,286 & 4,502 & 6,986 & 9,459 & 11,575 & 13,570 & 43,312 & 82,622 & 81,496 & 81,478 & 73.313 \\
\hline Mississippi & 13,143 & 12,643 & 16,871 & 20,615 & 21,709 & 23,417 & 25,547 & 30,713 & 50,220 & 85,670 & 114,599 & 112,243 & 100,179 \\
\hline Montana . . . . & 483 & 2,693 & 4,256 & 6,180 & 5,564 & 6,884 & 7,732 & 8,208 & 12,659 & 21,694 & 53,733 & 47,879 & 51,827 \\
\hline Nebraska & 631 & 525 & 722 & 958 & 1.113 & 1,131 & 1,242 & 1,516 & 2,948 & 4,196 & 6,010 & 5,217 & 4,539 \\
\hline New Mexico & 34,877 & 35,916 & 42,737 & 69,641 & 86,150 & 100,615 & 128,678 & 138,511 & 191,281 & 290,288 & 352,415 & 327,445 & 338,476 \\
\hline North Dakota & 3,306 & 3,140 & 4,358 & 6,880 & 8,283 & 9,288 & 10,730 & 13,533 & 29,687 & 87,560 & 169,225 & 166,781 & 176,793 \\
\hline Ohio & 176 & 1,042 & 1,063 & 1,068 & 1,064 & 1,146 & 1,111 & 1.436 & 1,609 & 1,712 & 1,750 & 1,680 & 3.964 \\
\hline Oklahoma & 73,342 & 71,456 & 96,980 & 128,096 & 151,316 & 191,351 & 230,368 & 280,982 & 436,098 & 601,486 & 742,701 & 777,687 & 703,738 \\
\hline South Dakota & 0 & 0 & 0 & 0 & 0 & 0 & 346 & 320 & 437 & 1,270 & 859 & 853 & 791 \\
\hline Tennessee & 0 & 0 & 0 & 0 & 0 & 0 & 38 & 26 & 250 & 504 & 521 & 1446 & 1236 \\
\hline Texas & 307,368 & 334,798 & 518,229 & 662,089 & 795,903 & 902,801 & 955,050 & 1021017 & 1519937 & $2,192,886$ & $2,373,847$ & $2,251,314$ & 2215350 \\
\hline Utah & 1,432 & 1,530 & 2,421 & 5,896 & 6,992 & 6.441 & 6,643 & 6,175 & 6975 & 11,661 & 18,040 & 17,354 & 34763 \\
\hline West Virginia & 0 & 0 & 0 & 0 & 0 & 0 & 0 & 0 & 0 & 0 & 0 & 0 & 0 \\
\hline Wyoming .... & 5,075 & 5,307 & 5,086 & 18,543 & 40,691 & 45,972 & 48,305 & 57,141 & 62757 & 78,387 & 287,763 & 271,131 & 267167 \\
\hline U. S. Total .. & 700,788 & 755,959 & $1,117,525$ & $1,531,419$ & $1,712,645$ & $1,860,396$ & $2,079,232$ & $2,296,411$ & $3,497,210$ & $5,646,380$ & $6,966,452$ & $6,640,086$ & $6,533,091$ \\
\hline
\end{tabular}

Sources: U.S. Bureau of the Census, Series, GF/84-1, State Government Tax Collections: 1984, U.S. Government Printing Office, Washington, DC, 1986, and earlier issues. 
Table A8. State Government Coal Severance Tax Receipts, Fiscal Years 1972-1984 (Thousand Dollars)

\begin{tabular}{|c|c|c|c|c|c|c|c|c|c|c|c|c|c|}
\hline State & 1972 & 1973 & 1974 & 1975 & 1976 & 1977 & 1978 & 1979 & 1980 & 1981 & 1982 & 1983 & 1984 \\
\hline Alabama & 2,040 & 2635 & 1,771 & 1,507 & 843 & 672 & 0 & 3,240 & 570 & 3,108 & 3,847 & 3,106 & 3,454 \\
\hline Colorado & 37 & 38 & 45 & 46 & 58 & 76 & 801 & 8,274 & 11,132 & 10,595 & 11,736 & 11,297 & 16,379 \\
\hline Kansas & 0 & 0 & 0 & 0 & 0 & 0 & 0 & 0 & 0 & 0 & 0 & 0 & 306 \\
\hline Kentucky & 5,767 & 37226 & 53,495 & 98,740 & 91,078 & 112,597 & 127,765 & 153,613 & 176,368 & 178,759 & 237,882 & 201,815 & 191,845 \\
\hline Montana . & 2,668 & 2694 & 3,315 & 5,396 & 22,924 & 34,470 & 33,624 & 42,049 & 75,125 & 70,415 & 86,187 & 80,045 & 82,824 \\
\hline New Mexico .. & 30 & 32 & 70 & 183 & 270 & 1,308 & 3,565 & 5,479 & 8,046 & 13,288 & 17,052 & 17,833 & 19,434 \\
\hline North Dakota & 0 & 0 & 0 & 0 & 4,311 & 6,130 & 7,889 & 11,970 & 14,240 & 15,830 & 17,460 & 17,746 & 22,760 \\
\hline Ohio & 555 & 2136 & 2,012 & 1,928 & 2,070 & 1,997 & 1,937 & 2,124 & 2,075 & 1,718 & 1,648 & 1,334 & 1,404 \\
\hline Tennessee & NA & NA & 810 & 1,595 & 1,818 & 2,052 & 2,098 & 2,129 & 1,954 & 2,048 & 1,991 & 1,973 & 2,099 \\
\hline Wyoming & NA & NA & NA & NA & 283 & 997 & 17,716 & 30,278 & 42,943 & 59,938 & 101,598 & 117,765 & 121,133 \\
\hline U.S. Total ... & 11,097 & 44,761 & 61,518 & 109,395 & 123,655 & 160,299 & 195,395 & 259,156 & 332,453 & 355,699 & 479,401 & 452,914 & 461,638 \\
\hline
\end{tabular}

Sources: U.S. Bureau of the Census, Series, GF/84-1. State Government Tax Collections: 1984, U.S. Government Printing Office, Washington, DC, 1986, and earlier issues. 